\title{
EFFECTIVE DEVELOPMENT INSTITUTIONS
}

\author{
Victoria M. Kuzenkova \\ PhD-student, the Department of Politics and Governance, \\ Faculty of Social Sciences, National Research University \\ Higher School of Economics. \\ Address: 20 Myasnitskaya Str., 101000 Moscow, \\ Russian Federation. \\ E-mail: vkuzenkova@hse.ru
}

\begin{abstract}
Development institutions are the most important tool for stimulating innovation processes and infrastructure development. These organizations finance long-term investment projects that contribute to the socio-economic development of the industry, region or country. Such specificity of activity leads to significant difficulties in the assessment of their efficiency. At the same time, the development of a system for assessment of the development institutions' efficiency, improving the efficiency of their work and ensuring positive economic growth rates in regions and states, are impossible without studying the approaches to the assessment of their efficiency.

A growing interest in the activities of multilateral development institutions is taking place in today's literature on public administration. However, there are currently no review articles that would consider the scope of work devoted to the assessment of the development institutions' efficiency. The review examines modern research publications that assess the results of individual development institutions and their contribution to socio-economic development and some issues of economic efficiency. The article analyzes various approaches and methods for assessment of the development institutions' efficiency. The study will allow us to assess the potential for use of modern approaches and identify areas for further application of the used methods.

The materials of the review can be used as a general theoretical part for teaching the disciplines of "public administration" related to the assessment of the public administration efficiency.
\end{abstract}

Keywords: development institutions; effective development institutions; development institutions' efficiency; assessment of the development institutions' efficiency.

Citation: Kuzenkova, V. M. (2021). Effective Development Institutions. Public Administration Issues, no 5 (Special Issue I, electronic edition), pp. 161-175 (in English). DOI: 10.17323/1999-5431-2021-0-5-161-175 


\section{Introduction}

The development of the new public administration concept has led to increased research interest in the issues of efficiency and its assessment in public administration. Currently, many methods of assessment of the public administration's efficiency have been developed.

These methods include the calculation of the indicators for assessment of the government, the labor market, the fight against corruption, macroeconomic stability, innovation potential, etc.

At the same time, development institutions are a relatively new tool for implementing the state's innovation policy. Therefore, there are currently no generally accepted methods or indicators for assessment of their efficiency. It is necessary to determine the essence of these organizations and the specifics of their activities to understand what approaches to the assessment of their efficiency can be used.

\section{The essence of development institutions}

According to the dynamics of development institutions research (Fig. 1 and 2), it is clear that the number of studies conducted prior to the 90s was significantly lower than at present - about three to five studies per year against 200-300.

For a while, there was a weak positive or volatile trend, but the number of studies on development institutions has steadily increased since the beginning of the 2000s.

This fact indicates the ever-increasing interest in the activities of these organizations, as well as the fact that the study of the development institutions' problems is at a relatively early stage.

\section{Figure 1: The number of documents by year for the "development banks" query in the Web of Science database, pcs.}

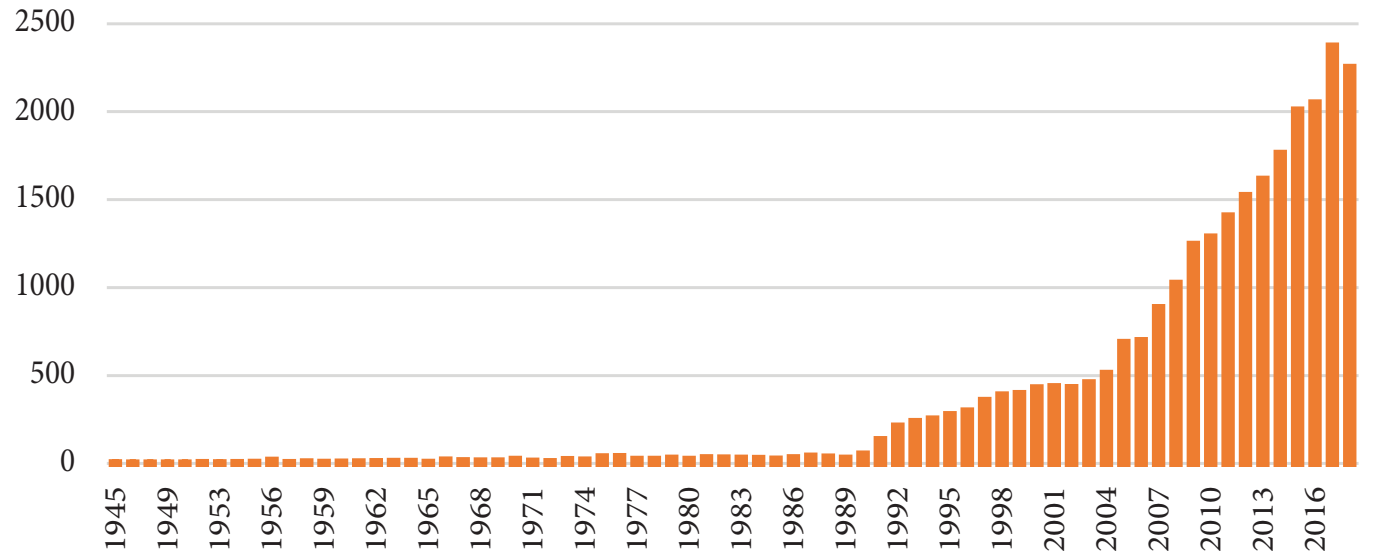

Source: Compiled from Web of Science statistics. 


\section{Figure 2. The number of documents by year for the "development banks" query in the SCOPUS database, pcs.}

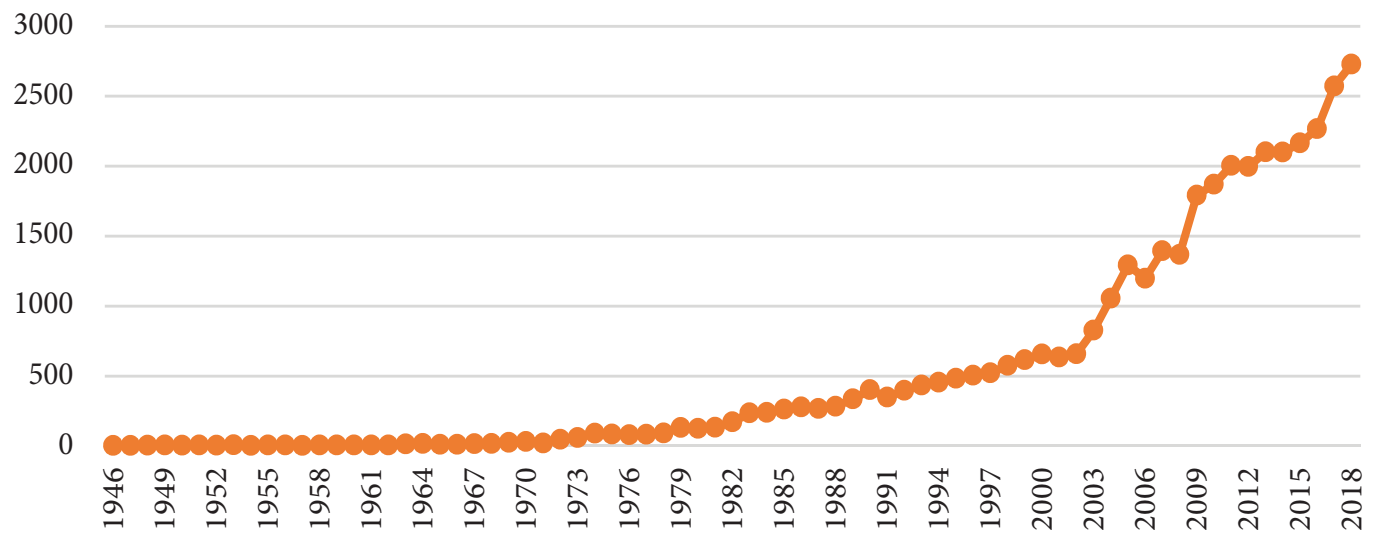

Source: Compiled from Web of Science statistics.

It should be noted that development institutions do not have a universal form or a single status in world practice. State governments assign special tasks to these organizations, so special rules and laws are adopted for them. This is due to the fact that many of the functions performed by development institutions are difficult to implement due to financial constraints. The governments of many countries used development institutions as an anti-crisis tool during the global crisis and huge market overloads, because resources from traditional banks were not enough (Dezhina, 2013).

These facts determine the features of development institutions' research. Most of them are studied in isolation, and the essence of development institutions is still very vague. Thus, the concept of development institutions is actively used in Russia but has not been widely used abroad. Most research focuses on development banks, despite the existence of different forms of development institutions: banks, agencies, corporations, and development associations. Let us compare the number of documents requested by development institutions and development banks in the SCOPUS database. At the request of development institutions, there are only 584 of them, while at the request of development banks - 3513. It can be noted that a similar approach to the study of development institutions existed in Russia. Only in recent years have researchers drawn attention to the fact that development institutions as a whole form a powerful innovation system of the state's economy, so they need to be studied together.

Currently, the concept of a development institution is not interpreted unambiguously. For example, the Association of European Development Finance Institutions defines development institutions as organizations that promote economic and socially sustainable development by financing profitable private sector enterprises. The Office of Foreign Assets Control (The U.S. Treasury Department), which is responsible for regulating development banks and financial institutions, defines a development institution as a financial institution that creates economic opportunities for individuals and small businesses (Frumina, 2017). 
Russian scientists also could not come to a consensus in the interpretation of the development institutions' concept. For example, a development institution is interpreted as an established form of interaction between economic agents, the result of which is a change in the system (Popov, Vlasov \& Simakhina, 2010). Or: development institutions are organizations created as an instrument of economic policy in its various manifestations (Bakhtazin, Valentik \& Buchwald, 2015). Some definitions use terms that are not well-established in research and regulatory activities or practice, which makes understanding the essence of development institutions even more difficult. Thus, development institutions are understood as specialized state corporations whose activities are aimed at eliminating "market failures" that hinder the economic and social development of a country (Solntsev, Khromov \& Volkov, 2009).

In this article, we will understand development institutions as organizations whose main activity is to stimulate innovation processes and develop infrastructure by financing long-term investment projects that contribute to the socio-economic development of the industry, region, country, and association of states.

The diversity of existing development institutions allows us to classify them according to various criteria:

- by territorial: national and foreign (Forster, 2018) or multilateral (global, regional, sub-regional) and national (Spivachevsky, 2012);

- by the nature of the impact on the environment of organizations: financial and non-financial (Monastyrsky \& Saklakov, 2011);

- $\quad$ in the field of activity: research funds, venture funds, institutions to support small and medium-sized businesses, institutions aimed at the development of economic and social infrastructure, etc.

- $\quad$ by type of financing: budget-funded and with a mixed capital structure;

- and others.

The issue of the classification of development institutions is the most important element that precedes the assessment of their efficiency. The goals, objectives and indicators of the efficiency of the scientific fund would significantly differ from those characteristics of the venture development institute, and the regional development institute from the global one, and the methods of the assessment of the efficiency of spending the invested funds will depend on the nature of the financing of the institute in question.

\section{Evolution of approaches to the assessment of the development institutions' efficiency}

The changing global economic conditions, the development and implementation of the latest management tools, and the development of state functions in the management of public finances, have all contributed to the evolution of the assessment methodology of the development institutions' efficiency over the past two decades.

Systematizing modern methodological approaches to the assessment of the activities of development institutions, we can distinguish three of the most common: 1. Assessment of the development institutions' efficiency as an economic entity (Nidar, Anwar, Komara \& Layyinaturrobaniyah, 2020; Gurara, Pres- 
bitero \& Sarmiento, 2020; Nalaukai, 2015; Heldt \& Schmidtke, 2019; BresserPereira \& Bechelaine, 2019; Mendez \& Houghton, 2020; Malkin \& Momani, 2016; Sanders, 2019; Silvestrov, Molodtsov \& Skorikov, 2013; Nelson, 2020; Nehru, 2014; Wang, 2017; Munir \& Gallagher, 2020; Sidorova \& Tatarkin, 2016; Yudina, 2015; Perfilova, 2017; Sukharev, 2017).

The formation of this approach is associated with the development of the concept of new public management, which is based on the idea of the similarity of management mechanisms in public and private organizations and the possibility of improving the efficiency of public administration through the introduction of market principles. At the same time, it is important to note that the financing of the activities of development institutions is carried out on a debt basis, through the issuance of bonds. Budget financing is used only at the stage of formation of the authorized capital. Given the significant limitations of bond loans, it turns out that development institutions, after their formation, should be guided by the market principles of self-sufficiency and self-financing. That is why, in most cases, researchers are interested in the question of financial efficiency. On the one hand, this approach can be called justified, since development institutions do not have constant funding from the participants. Receiving the majority of capital at the time of creation, these organizations must ensure their existence and financial stability for further functioning within the framework of the designated goals. On the other hand, such an approach would not be considered correct, since the goals of development institutions are not exclusively economic.

These features lead to the impossibility of applying other approaches, for example, methods for efficiency assessment of public-private partnership projects. These methods are based on the calculation of different groups of indicators, depending on the project participant. For example, in the case of a project that will result in a significant increase in tax revenues to the budget and a reduction in the unemployment rate, but the return on investment will be only $1 \%$, the state will be interested in its implementation, while the private investor will refuse. For multilateral development institutions, in this case, non-standard methods are needed to evaluate the project, acting both on behalf of the state and on behalf of the private investor.

There is a need to take into account both financial indicators and indicators of socio-economic development in such a way that their results allow us to resolve the contradictions generated by the specifics of their activities and financing of multilateral development institutions.

2. Assessment of the development institutions' efficiency as a semi-commercial and semi-governmental organization, taking into account its goals and objectives and industry specifics (Al-Busaidi \& Al-Muharrami, 2020; Simpasa, Shimeles \& Salami, 2015; Corral \& McCarthy, 2020; Nemlioglu \& Mallick, 2020; Nasreen, Mahalik, Shahbaz \& Abbas, 2020; Iheonu, Asongu, Odo \& Ojiem, 2020; Delikanli, Agolli \& Dimitrov, 2018; Kellerman, 2019).

As mentioned previously, the main purpose of development institutions is to form and develop an effective innovation economy, attract private capital on the principles of public-private partnership, modernize high-tech industries and, 
as a result, ensure the socio-economic development of a country. In this regard, the development institutions' efficiency should be assessed not only as its efficiency as an economic entity, but also taking into account the impact of investment projects on the socio-economic development of individual regions, states or interregional associations, which can be assessed using indicators of economic growth and social development.

3. Assessment of the development institutions' efficiency on the type of policy network (Ferry, Hafner-Burton \& Schneider, 2020; Opršal, Harmáček, Vítová et al., 2020; Rommel \& Schaudt, 2020; Dreher, Sturm \& Vreeland, 2009; Asongu, Nnanna \& Tchamyou, 2020; Lim \& Vreeland, 2013; Antropov, 2019; Leksyutina, 2018; Alvarez, 2016; Abalkin, 2006; Türkelli, 2020; Bradlow, 2019; Ella, 2020).

This theory, which is based on the concept of "policy network", is becoming increasingly popular and influential among public administration theorists. The concept of political networks is based on the same idea as new public management: the modern state will not be able to meet the needs of society, and therefore there is an urgent need to replace hierarchical administration with a new form of government. In the search for new approaches, new public management focuses on the market economy, and the theory of political networks puts the communicative processes of post-industrial society and the democratic practice of modern states at the center of the analysis. For the production of public goods, the state is increasingly dependent on other actors and subsystems. In this situation of interdependence between public and private actors, neither hierarchy nor the market are effective structures for coordinating the interests and resources of the various actors involved in the production of political decisions. As a result, policy networks become the dominant model of governance. Political networks are characterized by a variety of governance mechanisms, including not only state and non-state political structures, but also business, as well as a combination of various elements of civil society at different levels from international to local. Thus, management networks can consist of a number of different multi-level institutions united to solve a specific management task.

Let us look at these approaches in more detail.

\section{Assessment of the development institutions' efficiency}

\section{as economic entities}

The efficiency of regional development institutions can be measured by indicators such as the share of inefficient loans, capital adequacy ratio, return on assets, etc. (Nidar, Anwar, Komara \& Layyinaturrobaniyah, 2020). These indicators are traditionally used in the practice of the assessment of credit institutions' efficiency. Since the main mechanism of investment by development institutions is the issuance of loans for the implementation of selected projects, the researchers concluded that it is permissible to borrow these indicators and that they can be applied to the assessment of the efficiency of development institutions. In addition, using the parametric approach, the authors identified the factors that have the greatest impact on performance indicators. 
The efficiency of development institutions can be assessed as the total efficiency of their projects, based on the indicators of investment analysis $(\mathrm{Gu}-$ rara, Presbitero \& Sarmiento, 2020). In the assessment, the authors use indicators of net present income, profitability, and return on investment indices. It is worth noting that in an investment analysis, these indicators are used to make decisions about investing money before the start of the project, but not in the assessment of the results, since at the end of a long-term project, these values will differ significantly. In this case, it is not possible to adjust the activities of the institute to improve the indicators. The researchers also do not cover the issues of the efficiency assessment of operating activities or activities in international financial markets.

A number of studies with this approach (Nalaukai, 2015; Heldt \& Schmidtke, 2019; Bresser-Pereira \& Bechelaine, 2019; Mendez \& Houghton, 2020; Malkin \& Momani, 2016; Sanders, 2019) are devoted to the efficiency assessment of the largest Asian, American and African development institutions. For a comprehensive analysis in these works, the authors use a wide range of indicators: revenue, commercial and management expenses, profit, return on assets and liabilities, equity and debt capital, turnover of assets, capital, etc. However, there is a significant gap in the work of the group under consideration which is that most studies have limited their research to one or two institutions, as a result of which there is no understanding of whether it is possible to apply such an approach when comparing a large set of development institutions.

It is revealed, however, that individual development institutions may have additional goals and activities, so the assessment of their efficiency can be carried out using common indicators, but also taking into account the specifics of each institution (Silvestrov, Molodtsov \& Skorikov, 2013; Nelson, 2020; Nehru, 2014; Wang, 2017; Munir \& Gallagher, 2020).

Sidorova and Tatarkin (Sidorova \& Tatarkin, 2016) define the assessment of a development institute, as an economic entity, as an assessment of its ability to achieve its stated goals and objectives. This type of assessment focuses primarily on the efficiency of internal planning, since investment projects that qualify for state support and can only be implemented with the participation of development institutions, must meet special requirements. The assessment criteria include:

- maintaining optimal levels of financial independence ratios, in particular the ratio of equity and debt capital using effective management, financial and other tools;

- availability and sufficiency of resources to achieve the goals and objectives stated in the charter and other documents of strategic and business planning;

- high level of budget execution of the development institute, especially in the comparison of actual results with the initial objectives (Yudina, 2015).

As the information base for assessing the efficiency of development institutions as economic entities, their financial reports, financial and management reports are used. At the same time, common management methods such as horizontal, vertical, factorial, comparative, trend, and analysis of relative indicators are used (Perfilova, 2017). 
Among other things, indicators such as profitability, yield and others that take into account the industry specifics and organizational and legal forms of organizations, play a crucial role in assessing the efficiency of development institutions as economic entities. These indicators include:

- volumes and changes in the dynamics of revenue and profit indicators;

- volumes and changes in the dynamics of implemented investment projects;

- the growth rate of income of development institutions, the growth rate of expenses for their maintenance and the ratio of these growth rates;

- the optimal ratio of the amount of budget funds received for the implementation of the development institute's goals and objectives, and the cost of its maintenance (Sukharev, 2017).

In addition, one of the indicators of interest in this type of assessment is the ratio of the volume of management expenses to revenue. According to the research of the Financial Research Institute (the assessment of Russian and Foreign Development Institutions' efficiency, 2016), in Russian practice, the negative trend of exceeding the growth rate of expenses for the maintenance of development institutions over the revenue from their activities and net profit, is increasing. According to researchers, the increase in the cost of maintaining development institutions continues even in the presence of losses.

\section{Assessment of the development institutions' efficiency}

as a semi-commercial and semi-governmental organization, taking into account its goals, objectives and industry specifics

A number of researchers identify significant differences in the goals and objectives of development institutions and justify the need to use additional indicators that characterize the specifics of the activity.

It is confirmed that the assessment of development institutions' efficiency only based on uniform indicators leads to a distortion of the results (Al-Busaidi \& Al-Muharrami, 2020). The authors argue that it is acceptable to use common financial indicators of the efficiency of development institutions, but it is necessary to introduce non-financial criteria and indicators. Significant differences in the goals and activities of development institutions have been identified, which hinder the assessment of efficiency based on common indicators (Simpasa, Shimeles \& Salami, 2015; Corral \& McCarthy, 2020). Efficiency is proposed to be defined as "the total efficiency of implemented projects, assessed, in turn, taking into account their main purpose". The researchers propose to focus on the goals and objectives of the development institute and, accordingly, the projects implemented by it.

Another group of researchers studying the activities of development institutions offers a number of indicators that can be implemented in the assessment of these organizations' efficiency.

For example, Delikanli, Agolli and Dimitrov noted that the goal of most development institutions, as set out in their statutes, is to stimulate and promote sustainable economic development (Delikanli, Agolli \& Dimitrov, 2018). How- 
ever, the efficiency indicators used by these organizations do not correlate with this goal. According to the authors, the indicators of development institutions' efficiency can be borrowed from the set of global indicators developed by the special international group on indicators for achieving the Sustainable Development Goals and agreed by the United Nations Statistical Commission. These indicators should be adapted to the assessment of the multilateral development institutions' efficiency.

The efficiency of development institutions' investments can also be assessed based on the dynamics of indicators of socio-economic development of the countries that are their participants (Nemlioglu \& Mallick, 2020), for example, indicators of the efficiency of the economy and its real sectors, financial markets, banking, etc. (Nasreen, Mahalik, Shahbaz \& Abbas, 2020).

In addition, the most important criterion for the regional development institutions' efficiency is the dynamics of the financial development's level of recipient countries. Its analysis should take into account heterogeneity across countries and cross-industry dependence in the economy (Iheonu, Asongu, Odo \& Ojiem, 2020).

It is proved not only that development institutions have different goals and activities, but also that their widespread use has led to duplication of functions performed (Kellerman, 2019). In this case, the question of efficiency becomes more acute, since the disbanding of redundant institutions will lead to the release of budget funds that the economy of any state needs.

\section{Assessment of the development institutions' efficiency depending on the type of political network}

The formation of this approach is associated with the development of network theory along with the active spread of multilateral development institutions in recent decades. According to this theory, unions and associations, within which multilateral development institutions are created, are networks consisting of representatives of national governments, "arising spontaneously around individual problems, characterized by a minimal hierarchy of relations or its absence, a wide range of participants interacting based on the principles of mutually beneficial resource exchange to achieve common goals" (Slaughter, 2004). Such networks are created because it becomes more difficult for the modern state to ensure the satisfaction of public needs.

It is increasingly dependent on other actors. Neither the hierarchy nor the market is an effective structure for coordinating the interests and resources of the various actors involved in the decision-making process in this situation (Smorgunov, 2001). Therefore, the use of networks in public administration becomes necessary and effective.

A number of studies have proved that the leading countries of the associations, in defending their interests, exert political influence on the multilateral development institutions, forcing them to accept projects that do not meet the developed goals, objectives and efficiency criteria. 
For example, Lim and Vreeland concluded that countries with high influence in regional organizations use them to achieve their foreign policy goals (Lim \& Vreeland, 2013). Leksyutina argues that the creation of multilateral development banks is the result of the implementation of "foreign policy ambitions". Some of the policy decisions are aimed at tightening the requirements for the provision of assistance, which leads to the inability of individual countries to receive the necessary investments (Leksyutina, 2018). Alvarez claims that international organizations, especially multilateral development institutions, act in their political interests, in some cases violating the law. The improvement of international law proposed by The United Nations does not give the expected progressive results in solving this problem (Alvarez, 2016).

Another group of researchers did not identify the direct political influence of the leading countries of the associations on the multilateral development institutions but found difficulties faced by recipient countries due to non-compliance with the policies of donor countries.

It is proved that shifts in the policy of the donor country and the recipient country after the change of leadership lead to the redistribution of aid (Rommel \& Schaudt, 2020). Recipients have the opportunity to receive even more aid when their foreign policy position approaches that of the donor. In addition, a direct relationship between membership in the UN Security Council and the number of loans issued by the World Bank is revealed (Dreher, Sturm \& Vreeland, 2009). Opršal, Harmáček, Vítová et al. found that Poland and the Czech Republic provide investments to protect their geopolitical interests. These states prefer post-Soviet countries in the distribution of aid (Opršal, Harmáček \& Vítová et al., 2020). It is revealed that the efficiency of anti-corruption rules depends on the composition of donors (organizations that are part of development institutions): associations in which the majority of states are characterized by a high level of corruption are more likely to provide funds to similar states, and vice versa (Ferry, Hafner-Burton \& Schneider, 2020). Asongu, Nnanna and Tchamyou argue that the development institutions' efficiency can be assessed as changes in the banking and financial systems of recipient countries. These changes, in turn, depend on the level of regionalization and globalization (Asongu, Nnanna \& Tchamyou, 2020).

A number of studies draw attention to the existence of political influence, which, however, does not prevent the achievement of the goals of development institutions.

Türkelli concludes that multilateral development banks grant immunities and privileges to the member states. They are "hybrids": they perform the functionality that is documented in the goals, and also act as independent actors, making decisions about the implementation of certain projects for political reasons (Türkelli, 2020). Ella concludes that multilateral development institutions strive to maintain a balance between institutional efficiency and the realization of the geopolitical interests of the participating countries (Ella, 2020). Antropov proved that multilateral development institutions have common goals, but different areas of activity. Consequently, the efficiency of the chosen development institution should be assessed for each participant of the association separately 
(Antropov, 2019). Bradlow argues that the independent accountability mechanisms of the multilateral development institutions that monitor their compliance with the goals and objectives, as well as equal conditions in the provision of assistance, established by these organizations 25 years ago, now need to be updated (Bradlow, 2019).

\section{Conclusion}

To sum up, it can be noted that the scientific community actively studies the problems of the development institutions' efficiency. Currently, many approaches to the assessment of these organizations' efficiency have been formed.

Assessment methods of the development institutions' efficiency as economic entities allow one to assess its yield, profitability, business activity, etc. efficiency indicators. At the same time, making a profit is not the main activity of development institutions, so the assessment based only on these indicators cannot be correct.

Within the framework of the approach to the assessment of the development institutions' efficiency as semi-commercial and semi-governmental organizations, taking into account its goals, objectives and industry specifics, many separate criteria and efficiency indicators are proposed, but the lack of a single methodology makes it impossible to apply this approach in practice.

The approach to the assessment of the development institutions' efficiency depending on the type of political network is just beginning to develop. It is proved that the leading countries of the associations, in defending their interests, exert political influence on the multilateral development institutions, forcing them to accept projects that do not meet the developed goals, objectives and efficiency criteria. However, it is not yet clear how this information can be used and integrated into the assessment of the development institutions' efficiency.

Consequently, there is currently no comprehensive approach that would allow an objective assessment of the various institutions' efficiency and conduct a comparative analysis between them. In such conditions, it is possible to combine different approaches and compare the output data to increase the reliability of the assessment results.

It is expected that in further studies for a comprehensive assessment of the efficiency of development institutions, an integrated approach will be developed which provides for the calculation and analysis of the dynamics of indicators that characterize the socio-economic and commercial efficiency of activities; assessment of the contribution of development institutions to the socio-economic development of interstate associations, states and regions; assessment of the efficiency of budget management; comparison of the performance indicators of the analyzed development institute with the indicators of similar institutions. At the same time, some of the methods can be borrowed from existing approaches and adapted to the specifics of development institutions. The calculation of the integral indicator based on assessments that characterize various aspects of the activities of development institutions would allow one to assess a large set of different institutions and compare their efficiency. 


\section{REFERENCES}

1. Abalkina, A. (2006). Rol' mnogostoronnikh bankov razvitiya v sodeistvii ekonomicheskoi integratsii [The Role of Multilateral Development Banks in Promoting Economic Integration]. Bulletin of the Continent of Partnership, no 12, pp. 31-39.

2. Al-Busaidi, K.A. \& Al-Muharrami, S. (2021). Beyond Profitability: ICT Investments and Financial Institutions Performance Measures in Developing Economies. Journal of Enterprise Information Management, vol. 3, no 34, pp. 900-921.

3. Alvarez, J. E. (2016). International Organizations and the Rule of Law. New Zealand Journal of Public and International Law, vol. 1, no 14, pp. 3-46.

4. Antropov, V.V. (2019). Mnogostoronnie banki razvitiya v mirovoi ekonomike: osobennosti deyatel'nosti i perspektivy sotrudnichestva s Rossiei [Multilateral Development Banks in the World Economy: Features of Their Activities and Prospects for Cooperation with Russia]. Economy. Taxes. Law, vol. 1, no 12, pp. 98-109.

5. Asongu, S.A., Nnanna, J. \& Tchamyou, V.S. (2020). The Comparative African Regional Economics of Globalization in Financial Allocation Efficiency: The Pre-Crisis Era Revisited. Financial Innovation, vol. 3, no 6, pp. 1-41.

6. Bakhtazin, A. R., Valentik, O. N. \& Bukhvald, E. M. (2015). Instituty razvitiya kak instrument regional'noi ekonomiki [Institutions of Development as a Tool of Regional Economy]. Moscow: Institute of Economics of the Russian Academy of Sciences.

7. Balatsky, E. V. \& Ekimova, N. A. (2015). Effektivnost' institutsional'nogo razvitiya Rossii: al'ternativnaya otsenka [Efficiency of Russia's Institutional Development: Alternative Assessment]. Terra Economicus, vol. 4, no 13, pp. 31-51.

8. Bradlow, D.D. (2019). Multilateral Development Banks, Their Member States and Public Accountability: A Proposal. Indian Journal of International Economic Law, Forthcoming. Available at: https://ssrn.com/abstract=3404157 (accessed: 12 December 2020).

9. Bresser-Pereira, L.C. \& Bechelaine, C. (2019). Multilateral Development Banks, New Developmentalism and Local Currency Financing. Revista de Economia Politica, vol. 4, no 39, pp. 755-767.

10. Corral, L.R. \& McCarthy, N. (2020). Organisational Efficiency or Bureaucratic Quagmire: Do Quality-At-Entry Assessments Improve Project Performance? Journal of Development Studies, vol. 4, no 56, pp. 765-781.

11. Dezhina, I.G. (2013). Instituty razvitiya: chto izvestno ob ikh effektivnosti? [Institutions of Development: What Is Known about Their Efficiency?]. The newspaper "Troitsky variantnauka", no 126, p. 4.

12. Delikanli, I.U., Agolli, R. \& Dimitrov, T. (2018). Multilateral Development Banks: Governance and Finance. London: Palgrave Macmillan. Available at: https://www.palgrave.com/ gp/book/9783319915234 (accessed: 6 December 2020).

13. Dreher, A., Sturm, J.-E. \&Vreeland, J. R. (2009). Development aid and international politics: Does membership on the UN Security Council influence World Bank decisions? Journal of Development Economics, vol. 1, no 88, pp. 1-18. 
14. Ella, D. (2020). Balancing effectiveness with geo-economic interests in multilateral development banks: the design of the AIIB, $\mathrm{ADB}$ and the World Bank in a comparative perspective. The Pacific Review. Available at: https://doi.org/10.1080/09512748.2020.1788628 (accessed: 21 November 2020).

15. Ferry, L.L., Hafner-Burton, E.M. \& Schneider, C.J. (2020). Catch me if you care: International development organizations and national corruption. The Review of International Organizations, no 15, pp. 767-792.

16. Financial Research Institute (2016). Otsenka effektivnosti deyatel'nosti rossiiskikh i zarubezhnykh institutov razvitiya [Assessment of the Efficiency of Russian and Foreign Development Institutions]. Moscow: Financial Research Institute, 2016.

17. Forster, T. (2018). CMFB Workshop on the Classification of Development Banks. Sector Classification and Rearrangement of Transactions. Available at: https:/circabc.europa.eu/ sd/a/aa6bb978-0c03-4e18-82f8-f5501199f12d/2018-11-13\%20CMFB\%20Workshop\%20 DB\%20-\%202a\%20-\%20Development\%20banks\%20sector\%20classification\%20and\%20 rearraged\%20transactions\%20-\%20T\%20Forster.pdf (accessed: 29 November 2020).

18. Frumina, S.V. (2017). Instituty razvitiya kak elementy gosudarstvennoi innovatsionnoi politiki [Development Institutions as Elements of the State Innovation Policy]. Scientific Bulletin of the Belgorod State University. Series: Economics. Information technology, vol. 23, no 272, pp. 52-60.

19. Gurara, D., Presbitero, A. \& Sarmiento, M. (2020). Borrowing Costs and the Role of Multilateral Development Banks: Evidence from Cross-Border Syndicated Bank Lending. Journal of International Money and Finance, 100. Available at: https://doi.org/10.1016/ j.jimonfin.2019.102090 (accessed: 03 December 2020).

20. Heldt, E.C. \& Schmidtke, H. (2019). Explaining Coherence in International Regime Complexes: How the World Bank Shapes the Field of Multilateral Development Finance. Review of International Political Economy, vol. 6, no 26, pp. 1160-1186.

21. Herrera, F. (1966). The Inter-American Development Bank and The Latin American Integration Movement. Journal of Common Market Studies, vol. 2, no 5, pp. 172-180.

22. Iheonu, C.O., Asongu, S.A., Odo, K.O. \& Ojiem, P.K. (2020). Financial sector development and Investment in selected countries of the Economic Community of West African States: empirical evidence using heterogeneous panel data method. Financial Innovation, vol. 1, no 6. Available at: https://doi.org/10.1186/s40854-020-00195-0 (accessed: 08 December 2020).

23. International Monetary Fund (2015). Making Public Investment More Efficient. Available at: http://www.imf.org/external/np/pp/eng/2015/061115.pdf (accessed: 25 November 2020).

24. Kellerman, M. (2019). The Proliferation of Multilateral Development Banks. Review of International Organizations, vol. 1, no 14, pp. 107-145.

25. Leksyutina, Ya.V. (2018). Funktsional'nye izmeneniya uchastiya Kitaya v mnogostoronnikh bankakh razvitiya: ot zaemshchika k kreditoru [Functional Changes in China's Participation in Multilateral Development Banks: From Borrower to Lender]. International Organisations Research Journal, vol. 1, no 13, pp. 80-98.

26. Lim, D. \& Vreeland, J. (2013). Regional Organizations and International Politics: Japanese Influence over the Asian Development Bank and the UN Security Council. World Politics, vol. 1, no 65, pp. 34-72. 
27. Malkin, A. \& Momani, B. (2016). An Effective Asian Infrastructure Investment Bank: A Bottom Up Approach. Global Policy, vol. 4, no 7, pp. 521-530.

28. McDonald, W. (1960). The Role of the Development Bank in Rural Credit. Australian Journal of Agricultural Economics, vol. 2, no 4, pp. 97-105.

29. Melnikov, R.M. (2012). Rezul'tativnost' i effektivnost' rossiiskikh finansovykh institutov razvitiya: podkhody $\mathrm{k}$ otsenke i puti povysheniya [Efficiency and Effectiveness of Russian Financial Institutions of Development: Approaches to Evaluation and Ways to Improve], Finance and Credit, vol. 21, no 21, pp. 2-10.

30. Mendez, A. \& Houghton, D.P. (2020). Sustainable Banking: The Role of Multilateral Development Banks as Norm Entrepreneurs. Sustainability, vol. 3, no 12, pp. 1-20.

31. Monastyrny, E.A. \& Saklakov, V.M. (2013). Klassifikatsiya institutov razvitiya [Classification of Development Institutions]. Innovation, vol. 9, no 179, pp. 59-65.

32. Nalaukai, L. (2015). Prospects of a Melanesian Spearhead Group Investment Bank. School of Economics Working Paper, no 3, pp. 1-29.

33. Nasreen, S., Mahalik, M.K., Shahbaz, M. \& Abbas, Q. (2020). How Do Financial Globalization, Institutions and Economic Growth Impact Financial Sector Development in European Countries? International Business and Finance, no 54. Available at: http://dx.doi. org/10.1016/j.ribaf.2020.101247 (accessed: 24 November 2020).

34. Nelson, M. (2020). Multilateral Development Banks: Overview and Issues for Congress. Available at: https://fas.org/sgp/crs/row/R41170.pdf (accessed: 03 December 2020).

35. Nemlioglu, I. \& Mallick, S. (2020). Does Multilateral Lending Aid Capital Accumulation? Role of Intellectual Capital and Institutional Quality. Journal of International Money and Finance, no 108. Available at: http://dx.doi.org/10.1016/j.jimonfin.2019.05.005 (accessed: 01 December 2020).

36. Nidar, S. R., Anwar, M., Komara, R., \& Layyinaturrobaniyah. (2020). Determinant of Regional Development Bank Efficiency for Their Sustainability Issues. Entrepreneurship and Sustainability Issues, vol. 1, no 8, pp. 1133-1145.

37. Nikonova, I. A. (2015). Effektivnost' i rezul'tativnost' finansovykh institutov razvitiya: otsenka i upravleniya [Efficiency and Effectiveness of Financial Institutions for Development: Assessment and Management]. Finance, no 4, pp. 54-56.

38. Opršal, Z., Harmáček, J., Vítová, P. et al. (2020). Polish and Czech foreign Aid: A 'Mélange' of Geopolitical and Developmental Objectives. Journal of International Relations and Development. Available at: https://doi.org/10.1057/s41268-020-00192-x (accessed: 26 December 2020).

39. Organisation for Economic Co-operation and Development (2019). DAC Criteria for Evaluating Development Assistance. Available at: http://www.oecd.org/development/evaluation/ daccriteriaforevaluatingdevelopmentassistance.htm (accessed: 14 December 2020).

40. Perfilova, O.V. (2017). Otsenka effektivnosti rossiiskikh finansovykh institutov razvitiya [Assessment of the Effectiveness of Russian Financial Development Institutions]. In: A. A. Sukiasyan (ed.). The Role and Significance of Modern Science and Technology for the Development of Society. Collection of Articles of the International Scientific and Practical Conference: In 3 parts, Omega Science. Pp. 145-147.

41. Rodríguez-Pose, A. (2013). Do Institutions Matter for Regional Development? Regional Studies, vol. 7, no 47, pp. 1034-1047. 
42. Popov.V., Vlasov M.V. \& Simakhina, A. (2010). Instituty regional'nogo razvitiya ekonomiki znanii [Institutions of Regional Development of the Knowledge Economy]. Regional Economy: theory and practice, no 4, pp. 67-83.

43. Rommel, T. \& Schaudt, P. (2020). First Impressions: How Leader Changes Affect Bilateral Aid. Journal of Public Economics, no 185. Available at: https://doi.org/10.1016/j.jpubeco. 2019.104107 (accessed: 23 December 2020).

44. Sanders, G.J. (2019). Co-Financing among Multilateral Development Banks of Major Infrastructure Projects. Manchester Journal of International Economic Law, vol. 1, no 16, pp. 102-106.

45. Sanford, J. (1975). Development Theory and the Multilateral Development Banks: An Assessment of the Effectiveness of Strategies Used in International Development Finance. American Journal of Economics and Sociology, vol. 2, no 34, pp. 175-195.

46. Silvestrov, S.N., Molodtsov, A.V. \& Skorikov, E.S. (2013). Tipologiya i sravnitel'nyi analiz deyatel'nosti institutov razvitiya [Typology and Comparative Analysis of the Activities of Development Institutions]. Economic and Law Issues, no 10, pp. 45-53.

47. Sidorova, E.N. \& Tatarkin, D.A. (2016). Instituty razvitiya kak instrument realizatsii gosudarstvennoi investitsionnoi politiki: analiz sovremennogo sostoyaniya, otsenka rezul'tativnosti [Development Institutions as a Tool for the Implementation of State Investment Policy: Analysis of the Current State, Efficiency Assessment]. Bulletin of Ural Federal University. Series Economics and Management, vol. 4, no 15, pp. 506-528.

48. Simpasa, M., Shimeles, A. \& Salami, A. (2015). Employment Effects of Multilateral Development Bank Support: The Case of the African Development Bank. African Development Review, no 27, pp. 31-43.

49. Slaughter A. M. (2004). A New World Order. New Jersey: Princeton University Press.

50. Smorgunov, L. V. (2001). Setevoi podkhod k politike i upravleniyu [Network Approach to Politics and Management]. The policy. Political studies, no 3, pp. 103-113.

51. Solntsev, O.G., Khromov, M.Yu. \& Volkov, R.G. (2009). Instituty razvitiya: analiz i otsenka mirovogo opyta [Institutions of Development: Analysis and Assessment of World Experience]. Problems of Forecasting (Studies of Economic Development in Russia), vol. 2, no 113, pp. 3-29.

52. Spivachesky, P.M. (2012). Mnogostoronnie banki razvitiya: klassifikatsiya, sushchnost', transformatsiya predposylok obrazovaniya [Multilateral development Banks: Classification, Essence, Transformation of Educational Prerequisites]. Finance and Business, no 1, pp. 88-94.

53. Sukharev, O.S. (2017). Instituty razvitiya: neobkhodimost' i effektivnost' [Development institutions: necessity and efficiency]. State audit. Law. Economics, no 2, pp. 8-16.

54. The Office of Foreign Assets Control (2008). Assessing Program Performance. Available at: https://georgewbush-whitehouse.archives.gov/omb/performance/index.html (accessed: 27 November 2020).

55. Türkelli, E.G. (2020). The Best of Both Worlds or the Worst of Both Worlds? Multilateral Development Banks, Immunities and Accountability to Rights-Holders. Hague Journal on the Rule of Law, no 12, pp. 251-281.

56. Yudina, V.I. (2015). Instituty innovatsionnogo razvitiya: problemy metodiki otsenki effektivnosti [Institutes of Innovative Development: Problems of Efficiency Assessment Methodology]. In: V. D. Petukhov (ed.) Innovative Development - from Schumpeter to the Present Day: Economics and Education. Collection of Scientific Articles Based on the Materials of the International Scientific and Practical Conference. Scientific consultant. Pp. 478-482. 